\title{
Farmer preferences for conservation incentives that promote voluntary phosphorus abatement in agricultural watersheds
}

\author{
L.H. Palm-Forster, S.M. Swinton, and R.S. Shupp
}

\begin{abstract}
Financial incentives are commonly used to promote voluntary adoption of agricultural best management practices (BMPs), but little is known about farmer preferences among alternative incentives. Using experimental procurement auctions, we evaluate how different conservation incentives affect farmer willingness to adopt BMPs that reduce phosphorus $(\mathrm{P})$ runoff, a major driver of harmful algal blooms in Lake Erie. We rank incentives (e.g., payment, BMP insurance, tax credit, and certification price premium) by the cost per pound of $\mathrm{P}$ runoff reduction. Payments and tax credits that target high impact areas of the watershed are more cost-effective than untargeted price premiums for product certification. Farmers demand higher payments for contracts offering BMP insurance (i.e., protection against yield loss from BMP use) due to uncertainty about how the program will be implemented and the reliability of indemnities, as well as anticipated transaction costs associated with the program. Understanding farmer preferences for different types of conservation incentives is critical to design agri-environmental programs that engage more farmers and cost-effectively enhance ecosystem services.
\end{abstract}

Key words: agri-environmental policy — best management practice (BMP) insurance-harmful algal blooms - Lake Erie-payments for environmental services (PES) - reverse auctions

\begin{abstract}
This research evaluates farmer preferences for conservation contracts offering four different incentives, including (1) direct payments, (2) direct payments with insurance for conservation practices, (3) tax credits, and (4) price premiums tied to stewardship certification. Financial incentives are commonly used to promote voluntary adoption of best (or beneficial) management practices (BMPs) in the United States, where farmers generally hold the property rights to manage their land as they deem appropriate (Lichtenberg 2004; Kroeger and Casey 2007; Norris et al. 2008). A substantial amount of research has examined payments for environmental services (PES) programs for cost-share or annual stewardship payments (Reichelderfer and Boggess 1988; Lambert et al. 2007; Claassen et al. 2008), but little is known about farmer preferences for other types of incentives. A better understanding of these preferences can help policymakers design cost-effective con-
\end{abstract}

servation programs to promote practices that reduce agricultural nutrient loss.

Despite the reported benefits of agricultural conservation practices, widespread adoption of many BMPs has not occurred. Many factors impact farmers' adoption decisions, including attributes of the innovation, farm and farmer characteristics, social influences, and farmers' risk perceptions and beliefs about how actions on their farm impact the environment (Feather and Amacher 1994; Edwards-Jones 2006; Prokopy et al. 2008; Wilson et al. 2014). Some conservation BMPs require additional management effort and may reduce profits due to higher operating costs or lower yields, especially in the first few years of adoption while the farmer is learning how to successfully incorporate the new practice(s) (Lambert et al. 2007). Other BMPs displace cropland (e.g., filter strips), creating high opportunity costs due to profits foregone on those parcels.

Determining what kind of economic incentives are most cost-effective is an essential step in maximizing environmental benefits from limited conservation funds. Cost-effectiveness can be achieved by allocating payments to the subset of conservation projects that result in the highest benefit per dollar spent, where the measure of benefit depends on the goals of the program. Research on conservation incentives largely focuses on two contract types: uniform cost-share payments (e.g., under the Environmental Quality Incentives Program [EQIP]) and annual stewardship payments (e.g., Conservation Reserve Program [CRP]) (Lambert et al. 2007; Claassen et al. 2008). These contracts provide farmers a direct payment for land management changes. Depending on farmers' tax liability, attitudes toward risk, and marketing strategies, alternative incentives may be attractive, including tax credits, BMP insurance, and price premiums for stewardship certification. If farmers' preferences affect their willingness to accept payments for BMP adoption, certain incentives may be relatively more cost-effective and hence able to expand the impact of a limited conservation budget.

Evaluating alternative incentive transactions is also interesting from a political standpoint because these transactions involve a variety of payers, some of whom may be able to mobilize funding outside of public conservation budgets. For example, price premiums for stewardship certification are a market-based PES financed by consumers in the private sector. Tax credits, on the other hand, are off-budget expenditures that are allocated through legislative decisions.

By comparing per-acre bids submitted in hypothetical conservation auctions, this research explores cost-effective ways to induce adoption of BMPs that reduce phosphorus (P) runoff by evaluating farmers' willingness to accept conservation contracts with different incentive designs.

Conceptual Framework. We present a conceptual model that elucidates the effect of farmer preferences on the cost-effectiveness of different types of conservation incentives

Leah H. Palm-Forster (corresponding author) is an assistant professor in the Department of Applied Economics and Statistics at the University of Delaware in Newark, Delaware. Scott M. Swinton is a professor and Robert S. Shupp is an associate professor in the Department of Agricultural, Food, and Resource Economics at Michigan State University in East Lansing, Michigan. 
(see Palm-Forster [2015] for a detailed theoretical model). Using a limited budget, a conservation agency seeks to maximize environmental benefits by providing financial incentives for voluntary adoption of agricultural management practices that generate desirable environmental outcomes. To implement a targeted conservation program, the conservation agency makes two decisions. First, the agency chooses which incentive transaction it will offer to motivate voluntary conservation actions. Second, the agency selects the set of farmers that will be accepted into the program and paid for their conservation actions.

Research has shown that heterogeneous costs and benefits of BMP implementation make uniform payments inefficient, as some farmers are overpaid for their actions while others decline to enroll due to inadequate compensation (Horowitz et al. 2009; Selman et al. 2008). However, without knowledge about farmer-specific costs and benefits, it is difficult for conservation agencies to design contracts that are attractive to farmers while still using funds cost-effectively. Conservation procurement auctions provide agencies with a way to allocate scarce funds among the most cost-effective projects by having farmers compete for contracts and accepting offers that provide the most environmental benefit per dollar spent (Claassen et al. 2008; Hellerstein et al. 2015).

Although reverse auctions are typically used to allocate payments under a standard direct payment incentive design, the conservation agency could offer different types of incentives. If the agency knows how alternative incentive contracts will influence bids and farmers' willingness to participate, the agency can design more cost-effective programs by choosing an incentive that results in lower requested payments per unit of environmental benefit procured.

Since the incentives that we are interested in testing are not offered in reality, experimental auctions are used to evaluate farmers' relative preferences among four incentive types. Farmers submit bids that represent the amount of funding that they would require per-acre to adopt one or more BMP. Then, biophysical models are used to predict the level of environmental benefit that can be achieved with the BMP. This prediction requires knowledge about the current management system in order to predict benefits from an alternative system using the pro- posed BMP. The bid amount and predicted environmental benefits are used to select the most cost-effective bids-i.e., the bids that provide the most environmental benefit using the limited conservation budget. In practice, conservation procurement auctions are typically designed such that the winning bidders receive the payment requested (Hellerstein et al. 2015). Thus, farmers face a tradeoff when choosing their bid-a higher bid increases their potential payment, but decreases the probability that the bid will be accepted because higher bids increase the agency's cost per unit of benefit.

We can analyze how bids differ among four types of incentives, including (1) direct payment, (2) a direct payment with free (i.e., fully subsidized) BMP insurance, (3) a tax credit, and (4) a price premium tied to stewardship certification. Analyzing relative bids reveals information about farmer preferences for the alternative transactions.

A farmer will only enroll in a conservation program if the expected benefits (utility) derived from being in the program are greater than the benefits from what they would normally do (their status quo utility). Expected benefits depend on anticipated changes in profitability, and they also depend on perceptions about the ease of participating in the conservation program. Program participation can affect profitability through changes in productivity that may occur because of using a different management practice and changes in costs if input requirements differ between the old and new management systems. Program attributes and anticipated conservation outcomes also influence utility. For example, Peterson et al. (2014) show that transaction costs arising from contract stringency can cause farmers to insist on a higher payment to adopt new management practices. We posit that willingness to enroll in conservation programs is affected by farmer perceptions about the benefits and costs of different incentive contracts, including their expectations about transaction costs that they will face as participants.

Environmental stewardship can also provide personal and reputation benefits for farmers. Juutinen et al. (2013) found that conservation motives decrease payments required by landowners participating in a Finnish conservation program. Similarly, Wilson et al. (2014) found that farmers who are more concerned about negative environmental impacts of nutrient loss were more willing to take additional conservation actions on their land.

Farmers' bids to participate in conservation programs reflect their preferences among program attributes, profitability effects, and nonmonetary impacts. For example, a farmer may require a tax credit amount that is lower than the amount of a direct payment necessary for them to adopt a BMP. If a farmer values tax credits more than equivalent direct payments, it indicates that conservation programs could be designed to be more cost-effective by offering tax benefits (deductions or credits) instead of making direct payments.

If farmers are risk averse and perceive higher risks from BMP adoption, they may insist upon a risk premium in the form of higher PES compensation. In this case, crop yield insurance linked to BMP implementation may be more cost-effective than payments (Mitchell and Hennessy 2003). BMP insurance contracts protect farmers from downside profitability risk tied to BMP adoption. In this study, a group policy is used that pays indemnities to farmers that implement a BMP if the county-wide average yield of BMP systems falls below the county-wide average yield of conventional systems. Group policies are designed to overcome moral hazard issues associated with individual policies that pay farmers for productivity losses based on on-farm yield comparisons between BMP fields and check strips (DeVuyst and Ipe 1999; Mitchell 2004; Baerenklau 2005). In principle, if a risk averse farmer was provided with fully subsidized (i.e., free) BMP insurance, then we expect a bid for a payment with free BMP insurance to be less than a bid for a direct payment alone because, when insurance is provided, farmers would not add a risk premium to the payment they request.

Certification of environmental stewardship represents an alternative means to induce improved agri-environmental management. Programs that certify environmental stewardship can induce conservation actions if farmers value benefits from certification (e.g., price premiums, increased market access, social recognition, and protection from future regulation). If farmers value the nonmonetary benefits from becoming certified, they may be willing to adopt BMPs for a price premium that pays less than a direct payment made privately. 
A conservation agency seeks to maximize environmental benefits using a limited budget for voluntary conservation incentives. Figure 1 presents the environmental contract curves that are created by plotting projects based on the cumulative environmental benefits that could be procured and the cost per unit of benefit for each project, where cost is based on the bids submitted. At a given level of environmental benefits, $E$, the area underneath the supply curve equals the budgetary outlay required to fund accepted bids in a program with attributes $\rho . E_{j}$ and $E_{h}$ represent the total benefits procured with a fixed budget $G$ in programs offering incentive $j$ and $h$, respectively. Area $b$ is equivalent to area $c$ such that the budgetary expenditure for program $h$ (i.e., $G_{h}=a+b$ ) equals the budgetary expenditure for program $j$ (i.e., $G$ $=a+c)$. In this example, the agency would prefer to offer a program with incentive $j$ and attributes $\rho_{j}$ because it would enable the program to procure greater environmental benefits $\left(E_{j}>E_{h}\right)$ with a fixed budget $(G)$.

\section{Materials and Methods}

Using experimental conservation procurement auctions, we evaluate farmer preferences for different conservation incentives by comparing bids for different types of contracts. Comparing conservation incentive designs requires controlling for other factors that may influence the cost-effectiveness of the program. Past research has shown that farmer willingness to accept PES depends on direct costs and benefits, opportunity costs, personal beliefs, and farm resources (Ma et al. 2012). To test preferences for different incentives, we used a questionnaire to identify farmer characteristics and then controlled for farm characteristics by presenting auction participants with hypothetical, "mock" farms at specific locations in the watershed. Mock farms allowed us to control for otherwise unobservable farm characteristics in a way that we could replicate at each auction site; they also facilitated the real-time ranking of bids using previously simulated environmental data for each farm. Participants earned money in the experiment based on the profitability of their mock farms. Their decisions in the experiment were not linked to real actions on cropland they own.

We conducted our experiments in the Maumee Watershed, which drains into western Lake Erie and is the single largest watershed draining into the Great Lakes.

\section{Figure 1}

Contract supply curves show the cost to procure an additional unit of environmental benefit, $E$, that can be procured in conservation programs $h$ and $j$ with attributes $\rho$, given a limited budget $G=a+b=a+c$. TP signifies total phosphorus.

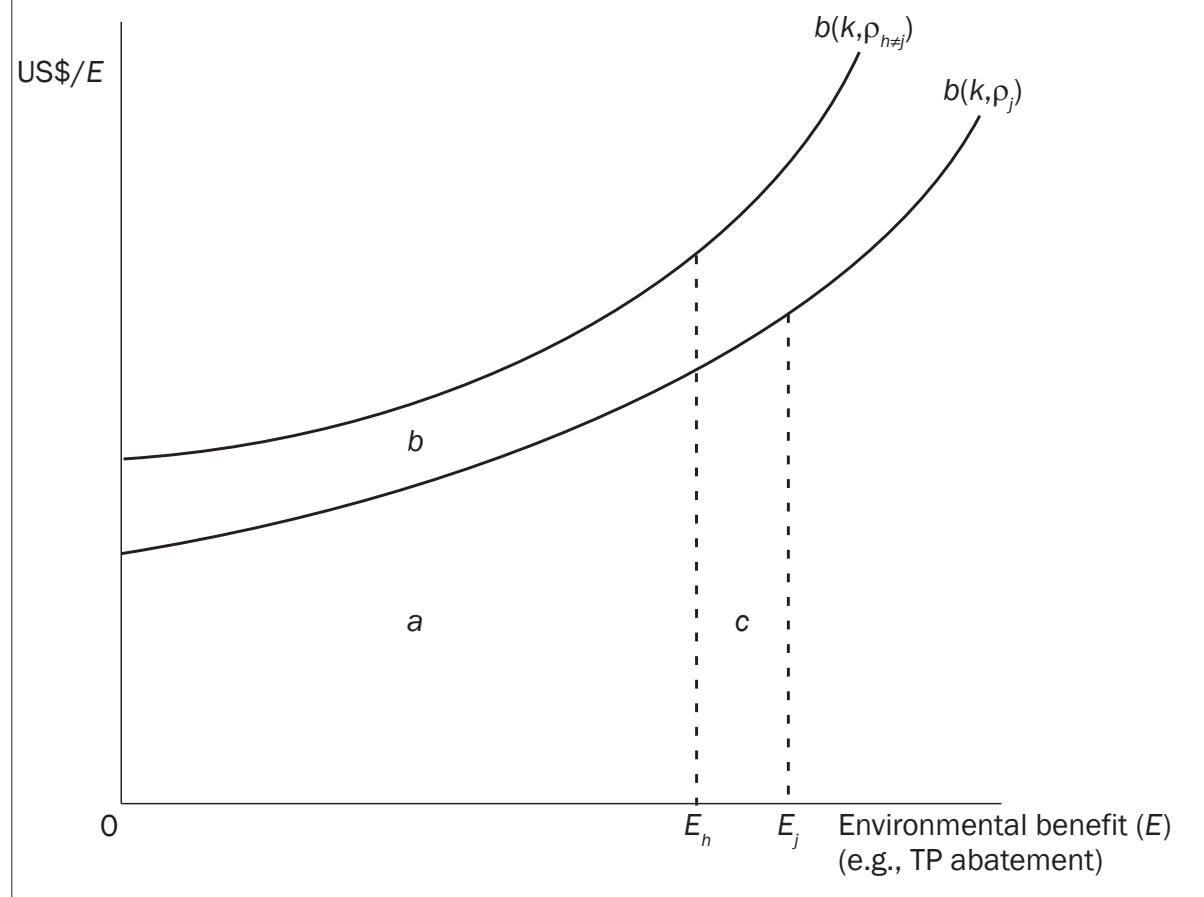

Spanning parts of Ohio, Michigan, and Indiana, $80 \%$ of the land in the Maumee is dedicated to agriculture. Recent research suggests that spring $\mathrm{P}$ loading from cropland in the Maumee Watershed is the primary driver of harmful algal blooms (HABs) in western Lake Erie (Stumpf et al. 2012; Johnson et al. 2014). Lake Erie HABs threaten human health and wildlife by producing microcystin, a harmful toxin that contaminated drinking water for nearly 500,000 people near Toledo in 2014. Furthermore, HABs reduce the value of lake recreation and associated tourism revenues (Palm-Forster et al. 2016a). Harder to quantify, hypoxic conditions caused by decaying algae affect high-valued fisheries in Lake Erie (Scavia et al. 2014).

To significantly reduce $\mathrm{HABs}$, experts estimate a need to lower annual total $\mathrm{P}$ (TP) loads by $40 \%$ to $46 \%$ (Johnson et al. 2014). Controlling soluble reactive P (SRP) export via surface runoff and subsurface drainage systems, particularly during the spring months, is critical to control nutrient export to the Great Lakes (Kleinman et al. 2015). The 2012 Great Lakes Water Quality Agreement (GLWQA) formalized a joint commitment from the United States and Canada to manage P loadings in Lake Erie
(IJC 2014). Recently revised water quality targets call for a $40 \%$ reduction in TP entering Lake Erie's western and central basins relative to 2008 levels and a $40 \%$ reduction in spring TP and SRP loads from several watersheds including the Maumee (USEPA 2016). Cost-effective conservation incentives to abate $\mathrm{P}$ runoff are clearly needed to augment the impacts of limited conservation budgets. In this research, we focus on the abatement of TP, but recognize the increasing importance of limiting SRP export in watersheds like the Maumee.

Developing and Pretesting the Auctions. Auction protocols were developed in three stages. The first stage involved the development, pretesting, and implementation of a simplified auction that was conducted with 72 students at Michigan State University. The second stage involved the development of the farmer experimental auction protocols, directions, and information handouts about mock farms and conservation practices.

Sixteen mock farms were developed to represent corn (Zea mays L.) and soybean (Glycine max L.) farms in the Maumee Watershed. Farms were clustered in four groups as depicted in figure 2. Pairs of farms had unique soil types and average crop yields, meaning that there were eight unique geo- 
graphic farm characteristics among the 16 mock farms (table 1). Crop yields and TP runoff from the mock farms were modeled using the Soil and Water Assessment Tool (SWAT) (Gassman et al. 2007), which was adapted for the Maumee Basin by Bosch et al. (2011) and further modified by LimnoTech (2013). Soil types were assigned based on the two predominant soil types in each farm cluster. SWAT parameters for crop yields for each farm were scaled to align with the average county yield reported by the USDA National Agricultural Statistics Service (USDA NASS 2014). See PalmForster et al. (2016c) for additional details about the SWAT model used in this study.

Table 2 presents an example of how the additional information was provided to participants about their mock farm. This information included location, acreage, soil type, cropping system, average crop yield and prices, and costs of conservation practices. Acreage, cropping system, and average crop prices were held constant across farms while soil type, average yield, and costs of conservation practices varied among mock farms to account for the heterogeneity among farms in the region.

Information about baseline production practices was provided to auction participants, including (1) planting and harvesting dates; (2) fertilizer application rate, source, and timing; (3) tillage practices; (4) cover crops; and (5) filter strip placement. The same

\section{Figure 2}

Locations of mock farms in experimental auctions in Maumee River Basin of northwest Ohio, southeast Michigan, and northeast Indiana.

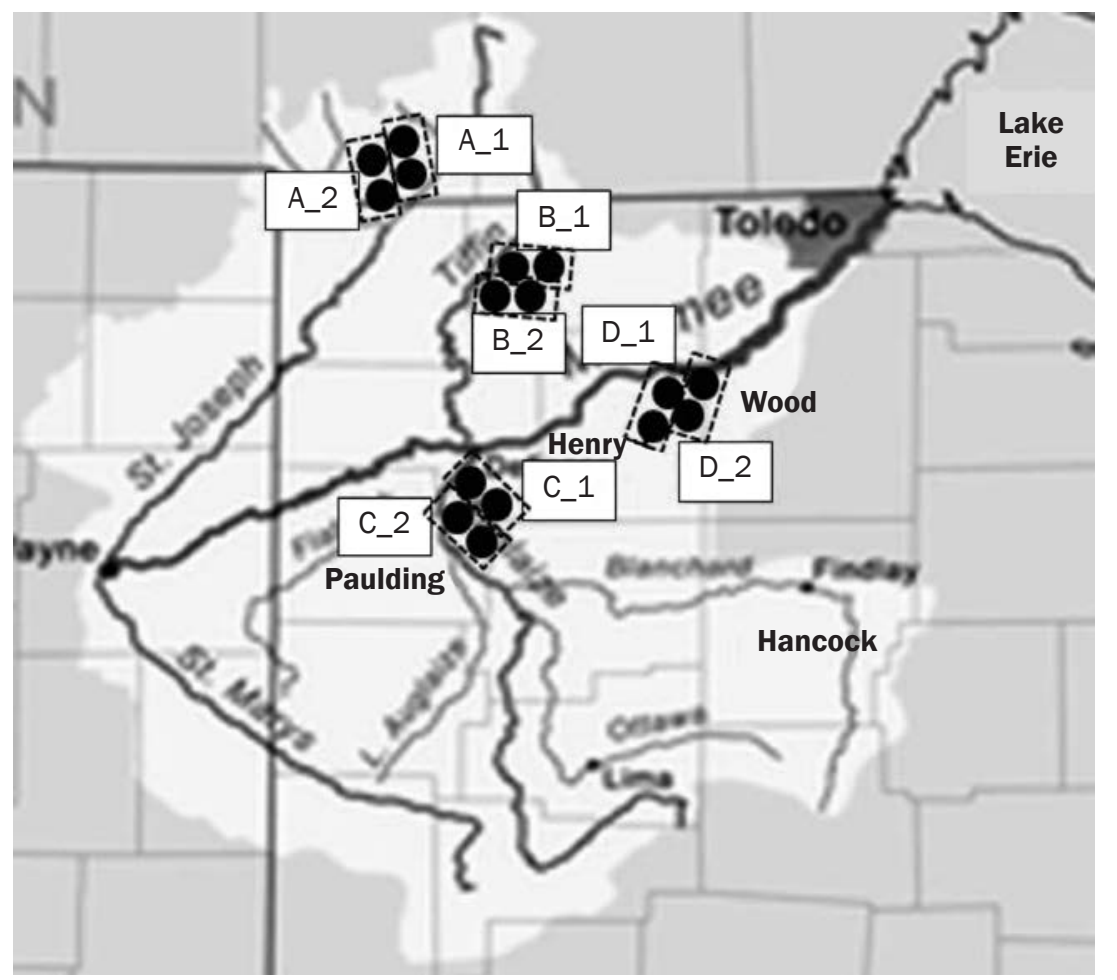

baseline cropping system was assumed for all mock farms and is presented in table 3 .

BMP implementation costs were designed to be representative of typical costs faced by Maumee producers and were selected from the following two sources: (1) the cost-share payment schedule for conservation projects in Ohio funded by USDA Natural Resources Conservation Service's (NRCS) Environmental Quality Incentives Program (EQIP) and (2) opinions from farmers interviewed at the Michigan State Ag Expo (East Lansing,

Table 1

Information given to experimental auction participants about mock farm location, soil type, and crop yields.

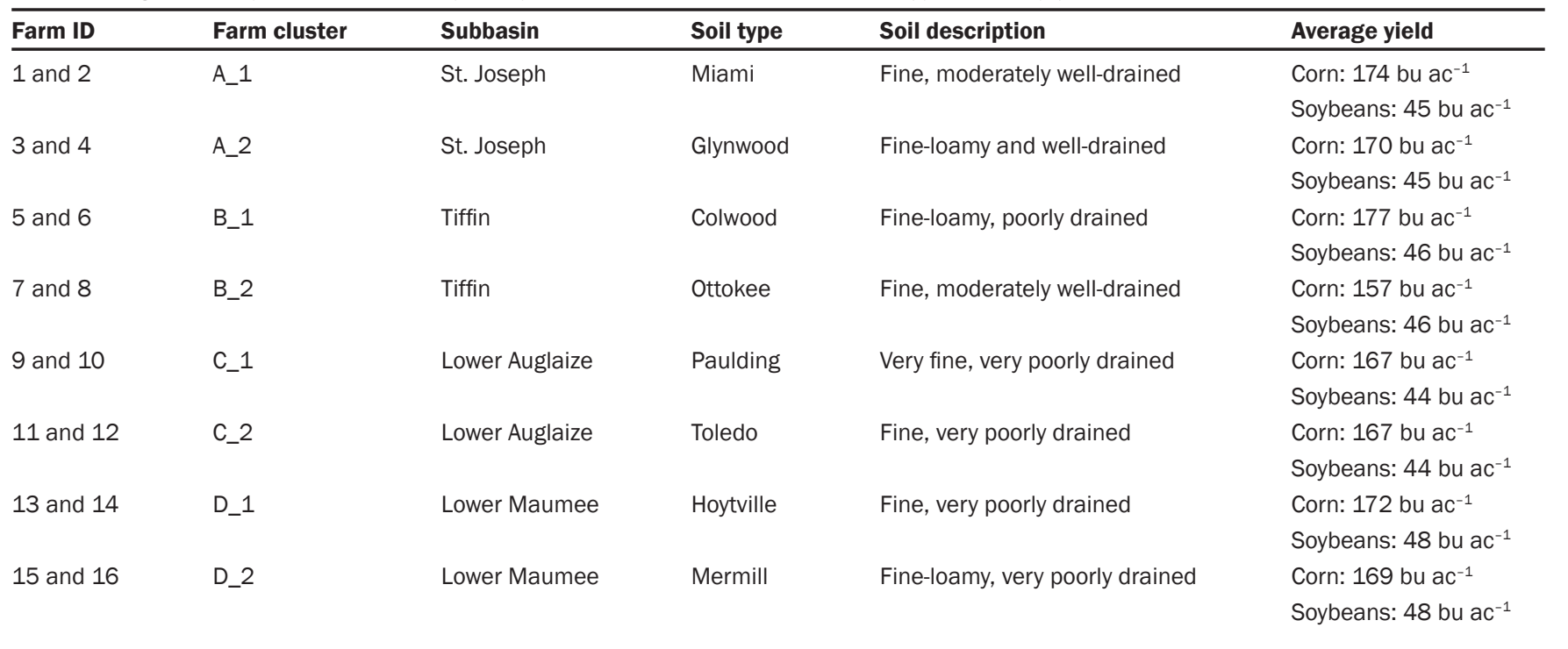




\section{Table 2}

Example information card for mock farms assigned in the experimental auction.

\begin{tabular}{|c|c|}
\hline Farm ID & Farm A-1 \\
\hline Acreage & You own 200 ac, which is divided into two 100 ac fields \\
\hline Soil type & Miami; fine, moderately well-drained \\
\hline Cropping system & $\begin{array}{l}\text { Corn-soybean rotation; assume that each year you grow } \\
100 \text { ac of corn and } 100 \text { ac of soybeans* }\end{array}$ \\
\hline Average yield and prices & $\begin{array}{l}\text { Corn: } 174 \mathrm{bu} \mathrm{ac}^{-1}\left(\mathrm{US} \$ 6 \mathrm{bu}^{-1}\right) \\
\text { Soybeans: } 45 \mathrm{bu} \mathrm{ac}^{-1}\left(\mathrm{US} \$ 12 \mathrm{bu}^{-1}\right)\end{array}$ \\
\hline Cost of conservation practices $\dagger$ & $\begin{array}{l}\text { Cover crop: US } \$ 20 \mathrm{ac}^{-1} \\
\text { Conservation tillage: US\$16 } \mathrm{ac}^{-1} \\
\text { No fall fertilizer (spring fertilizer instead): US } \$ 0 \mathrm{ac}^{-1}\end{array}$ \\
\hline
\end{tabular}

*Details were attached and are shown in table 3.

†Does not include costs or benefits of yield changes.

Michigan, July 18, 2013).A main-effects orthogonal design was used to assign four levels of BMP implementation costs to the 16 mock farms as presented in table 4 .

The final stage of pretesting involved vetting the mock farm descriptions and auction directions with farmers and experts, including specialists at The Ohio State University Extension, a crop and soil science professor at Michigan State University, and a nutrient management consultant from a northwestern Ohio agricultural retailer. Three farmers were recruited during the Michigan Ag Expo to review the auction directions and mock farm descriptions.
Design of Experimental Conservation Auctions. The experimental auctions were conducted at four farmer meetings in northwest Ohio. Personalized invitations to the auction meetings were mailed to 154 farmers. To enhance credibility, the cover letters that explained the purpose of the meeting were co-signed by leaders in the agricultural communities in which each meeting was held. These locations included Paulding County, Henry County, Wood County, and Hancock County. Producer addresses were obtained from four sources: (1) the local Soil and Water Conservation District (SWCD) office, (2) the Ohio Farm Bureau, (3) an agricultural input supplier in northwest Ohio, and (4) county property tax records.

Upon arrival, participants were asked to sign a consent form, they were paid a US $\$ 50$ participation honorarium, and they were provided with a folder that included details about their mock farm and general instructions. The auction leader presented an introduction and review of the instructions. In a series of seven auctions, farmers submitted bids for different types of incentives. Farmers were asked to make decisions for the mock farms as if these were their own farms. In this paper, we present the results from the first four auctions in which farmers submitted bids for different types of financial incentives. Results from the other auction rounds are discussed in Palm-Forster et al. (2016c).

Three protocols were consistently followed across all auction rounds. First, farmers were invited to submit bids for the annual per-acre payment (or tax credit/price premium, depending on the round) that they would require to adopt one or more of the following in-field conservation practices: (1) cover crops, (2) conservation tillage, and (3) spring fertilization instead of fall fertilization. If a farmer bid on more than one practice, then the group of practices was evaluated as a package. Combinations of practices were evaluated as packages for computational tractability so that environmental benefits for all possible combinations could be mod-

\section{Table 3}

Baseline crop production system for mock farms.

Description of cropping system: You own and farm 200 ac. Your land is divided into two 100 ac fields. Each year you produce corn on one field and soybeans on the other field. Following soybean harvest, corn land is field cultivated and fertilized in fall. Corn also receives starter and side dress fertilizer. Soybeans are no-till drilled into corn stubble with no fertilization. No cover crops. Details below.

\begin{tabular}{|c|c|c|}
\hline Variable & Corn field & Soybean field \\
\hline Plant & Mid-April to mid-May & May \\
\hline \multicolumn{3}{|l|}{ Tillage (before corn) } \\
\hline Type & - & Field cultivator \\
\hline Time & - & October or November \\
\hline Fertilizer application & $\begin{array}{l}\text { (1) Starter fertilizer: UAN } 28 \% \text { and liquid } \\
\text { ammonium polyphosphate mixed to: } \\
\text { N-P-K } 17-20-00 \text { applied at a rate of } \\
18 \text { gal } \mathrm{ac}^{-1} \text { on the day of planting. } \\
\text { (2) Side dress: UAN } 28 \% \text { : N-P-K } 28-00-00 \\
\text { applied at a rate of } 41.5{\text { gal } \mathrm{ac}^{-1} \text { six weeks }}_{\text {after planting. }}\end{array}$ & $\begin{array}{l}\text { (1) Broadcast (before corn): 08-15-00 + potash mixed to: } \\
\text { N-P-K 08-15-45 applied at a rate of } 200 \mathrm{lb} \mathrm{ac}^{-1} \text { in October or } \\
\text { November (after fall tillage). }\end{array}$ \\
\hline Harvest & End of October to November & October \\
\hline
\end{tabular}

Note: No filter strips. 
eled in SWAT before the auction session. Second, the average predicted reductions in TP surface export from adopting the conservation practices proposed in each bid were calculated using the SWAT model, which simulated an eight-year crop rotation. Third, bids were sealed and no information about outcomes was provided between rounds.

To familiarize farmers with the auction process, the first round involved farmers bidding for a direct payment, which is the most straightforward incentive transaction and is considered the reference case because direct payments are currently the predominant incentive used to motivate conservation. Auction learning effects were limited because farmers only learned about bid acceptance at the end of the session after all auctions had been completed. Auction sessions were designed in this way to limit strategic bidding and facilitate comparison of bids for alternative incentives to bids for direct payments (the reference case).

After the payment auction was completed, farmers were informed about BMP insurance that they would automatically receive if their bid for a payment was accepted in the second auction. Farmers were told that insurance indemnities would be paid if the countywide average yield of BMP systems fell below the countywide average yield of conventional systems. Farmers then submitted a bid for the payment that they would require to adopt a BMP when provided with the BMP insurance free of cost.

The tax credit auction was most similar to the direct payment auction, only with a different payment vehicle. Farmers submitted bids for the state tax credit that they would request in exchange for adopting conservation practice(s). State tax credits were offered to link regional environmental benefits and regional (state) incentives; however, participants at the first auction site (Paulding County) indicated that state tax liabilities for most farmers are less than the payment they would require to implement some conservation practices (e.g., cover crops on large acreage). In the latter three sessions (Henry County, Wood County, and Hancock County), we included an auction for federal tax credits in addition to the auction for state tax credits, as the level of federal taxes would be better able to fund conservation practices. Results between auctions for the two tax credits are similar; therefore, we report results

Table 4

Costs of conservation practices assigned for mock farms.

\begin{tabular}{|c|c|c|c|c|}
\hline Farm ID & $\begin{array}{l}\text { Cover crops } \\
\left(\text { US\$ } \text { ac }^{-1}\right)\end{array}$ & $\begin{array}{l}\text { Conservation } \\
\text { tillage } \\
\left(\text { US\$ } \mathbf{~ a c}^{-1}\right)\end{array}$ & $\begin{array}{l}\text { Spring } \\
\text { fertilizer } \\
\left(\text { US } \$ a c^{-1}\right) \\
\end{array}$ & $\begin{array}{l}\text { All three } \\
\text { BMPs* } \\
(\text { US\$ ac-1) }\end{array}$ \\
\hline $1(\mathrm{~A}-1)$ & 20 & 16 & 0 & 36 \\
\hline $2(\mathrm{~A}-2)$ & 24 & 16 & 1 & 41 \\
\hline $3(\mathrm{~A}-3)$ & 28 & 16 & 2 & 46 \\
\hline $4(\mathrm{~A}-4)$ & 32 & 16 & 3 & 51 \\
\hline 5 (B-1) & 20 & 20 & 1 & 41 \\
\hline $6(\mathrm{~B}-2)$ & 24 & 20 & 0 & 44 \\
\hline 7 (B-3) & 28 & 20 & 3 & 51 \\
\hline 8 (B-4) & 32 & 20 & 2 & 54 \\
\hline $9(\mathrm{C}-1)$ & 20 & 24 & 2 & 46 \\
\hline $10(\mathrm{C}-2)$ & 24 & 24 & 3 & 51 \\
\hline $11(\mathrm{C}-3)$ & 28 & 24 & 0 & 52 \\
\hline $12(\mathrm{C}-4)$ & 32 & 24 & 1 & 57 \\
\hline $13(\mathrm{D}-1)$ & 20 & 28 & 3 & 51 \\
\hline 14 (D-2) & 24 & 28 & 2 & 54 \\
\hline 15 (D-3) & 28 & 28 & 1 & 57 \\
\hline 16 (D-4) & 32 & 28 & 0 & 60 \\
\hline
\end{tabular}

*BMPs $=$ best management practices.

for state tax credits because this incentive was tested at all four auction sites.

In auctions for direct payments, payments with BMP insurance, and tax credits, bids were ranked based on the cost per pound of reduced TP runoff, and contracts were offered to the farmers who made the most cost-effective bids until the budget was exhausted. Farmers with selected projects were paid the amount of their bid. The budget for each auction was set at 100,000 experimental dollars, but was unknown to farmers.

The auctions for price premiums associated with a stewardship certification were implemented differently to reflect how price premiums would be awarded in reality. In practice, farmers enroll in a certification program if they are willing to accept the premium provided by the program. This enrollment rule can be mimicked using a Becker-DeGroot-Marschak (BDM) mechanism (Becker et al. 1964). In these auction rounds, farmers bid the minimum price premium they would accept to enroll in the certification program, and their bids were compared to a randomly drawn price premium. Price premiums for corn and soybeans were drawn from uniform distributions with known supports. Possible premiums ran from US $\$ 0$ to US $\$ 1$ for corn and US $\$ 0$ to US $\$ 2$ for soybeans in one-cent increments. If, for both crops, the price premiums requested by farmers were less than the premium drawn, then participants were enrolled in the stewardship certification program and they received the per bushel premium drawn. If their bids were greater than the randomly drawn price premium for either crop, the farmer was not enrolled in the program.

Unlike discriminatory price reverse auctions in which the winning bidders are paid the amount of their bids and have an incentive to bid strategically, the BDM mechanism has been shown to be incentive compatible (Lusk and Shogren 2007; Lusk et al. 2007). Incentive compatibility means that the mechanism induces the bidder to tell the truth about the lowest payment that they are willing to accept. If the BDM mechanism used to elicit bids for the certification price premium is incentive compatible, one would expect bids to be lower relative to bids for payments in a discriminatory price auction. The implications of using the two types of auctions are discussed when interpreting the results.

In addition to the US\$50 participation honorarium, participants were paid based on the total income generated by their mock farm in all auction rounds. Net winnings in each round equaled the difference in farm profits with and without the conservation program. Farm profits equaled the net revenue minus the costs of adopting the conservation practice(s) plus the income provided by the conservation incentive (e.g., payment, tax credit, or price pre- 
mium). Mock farm incomes were calculated for each auction round and then summed to calculate the total earnings. Payments for auction performance ranged from US $\$ 38.00$ to US $\$ 68.25$, with an average payment of US $\$ 52.00$.

Empirical Model. In the conceptual framework, we discussed how farmer preferences could cause conservation bids to differ by incentive type, thereby varying the cost-effectiveness of conservation contracts offering alternative incentives. However, a priori, we do not know whether or how preferences will differ among the incentive types. In an experimental setting, we can test the impact of different incentive types on the bids submitted by farmers with lower bids indicating that farmers are willing to adopt BMPs at a lower cost to the conservation agency.

To identify relative differences in bids submitted for various incentives, we focus on what we call "net bids," which is the difference between the bid amount and the known cost of adopting one or more BMPs (recall that farmers knew their costs). When a bid was submitted for a per-bushel price premium in the certification treatment, the net bid was calculated by multiplying the premium (bid) by the estimated per-acre crop yield and subtracting the per-acre costs of BMP implementation.

The net bid is impacted by expected changes in revenue from a yield effect, transaction costs of being involved with the conservation program, environmental attitudes and incentive type preferences, and the probability of bid acceptance. A linear specification is used in a regression model to estimate how the type of conservation incentive offered affects net bids (see PalmForster [2015] for more details).

The type of incentive offered in each auction is modeled with binary variables such that estimated coefficients reflect how much the bid will change when different incentives are offered compared to the baseline, which is the direct payment. We control for the type of $\mathrm{BMP}(\mathrm{s})$ included in each bid because they could impact farmer perceptions about the profitability effect. Farmer characteristics are controlled for with continuous and binary variables as presented in table 5. A binary variable was created to indicate if the farmer was a member of an environmental organization; the variable equals one if the farmer was a member of an environmental organization and zero otherwise. Additionally, binary fixed effect variables control for the mock farm cluster to which each farmer was assigned (table 1) and the location of the experimental auction session in which they participated. This specification enables tests of the following null hypotheses: (1) that incentive type has no effect on bid amount, and (2) that environmental preference (as proxied by organizational membership) has no effect on bid amount.

\section{Results and Discussion}

Outcomes from the experimental auctions are evaluated in two ways. First, we evaluate farmer preferences among incentive transactions by comparing their net bids (i.e., the difference between their bid and assigned cost of BMP implementation). Next, we evaluate the cost-effectiveness of the auctions based on how much environmental benefit was acquired per dollar.

Overview and Descriptive Analysis. Fiftyone farmers participated in the experimental auctions, yielding 49 records that could be used in the analysis because one participant was not a corn and soybean farmer and the other participant failed to complete the background questionnaire. Auction participants included in this analysis were recruited using mailing lists from county SWCDs (69\%), Ohio Farm Bureau (15\%), an input supplier (10\%), and property tax records (6\%). Characteristics of participants at each auction location are presented in table 5 .

Participants were all male with a mean age of 56 years and mean farming experience of 38 years. Forty-nine percent of participants had continued their education beyond high school and $45 \%$ of farmers were from households earning US\$50,000 or more in off-farm income. Participants were row crop farmers following a corn and soybean rotation with some farmers growing wheat (Triticum aestivum) in the rotation. In 2012, the farmer participants planted an average of $1,477 \mathrm{ac}$ ( $597 \mathrm{ha}$ ) in corn or soybeans on land that they owned or rented. Thirty-eight percent reported being a member of an environmental organization.

Farmer Preferences among Incentive Types. Farmer preferences among the four incentive types were evaluated by comparing net bids in each auction. The net bid was calculated for each farmer as the per-acre bid for that incentive transaction minus the assigned per-acre cost of BMP implementation. If farmers bid on multiple practices, the net bid was calculated by subtracting the total per-acre cost of all practices from the total per-acre bid and the practices included in each bid were controlled for in the econometric model. The only variable that differed among auctions was the type of incentive for which the farmers were bidding, thus changes in bidding behavior reveal farmer preferences among the four different incentive types.

Figure 3 summarizes the bidding behavior using a scatterplot of participant bids against their given implementation costs in four auctions. The 45 degree line connects points where bids equal monetary costs such that bids that exceed implementation costs are above the line and bids less than implementation costs are below the line. Two important results are apparent. First, the variation among bids is smallest in the auction for direct payments and greatest in the one for direct payments with BMP insurance. Greater variation among bids mirrors the variation in farmer preferences. Some farmers were interested in BMP insurance to minimize perceived downside yield risk associated with BMP adoption and thus required a lower payment when BMP insurance was provided free of cost. Other farmers showed strong aversion to BMP insurance by bidding for payments that far exceeded implementation costs.

Second, farmers bid both above and below their costs (figure 3). Previous studies have concluded that bidding below one's cost is a mistake that inexperienced farmers make when bidding in conservation auctions in an attempt to increase their chances of winning (Cason et al. 2003). However, the frequency of bidding below costs that occurred in this study suggests that other factors may be influencing farmers' bidding decisions. As presented in our conceptual framework, low bids may reveal farmers' environmental preferences or their expectations of private benefits from implementing the BMP(s). It is highly likely that farmers were considering their environmental preferences when submitting bids and this result is supported by the econometric analysis that follows. Participants took the experimental auctions seriously. During debriefing following the auction, farmers stated that they were willing to accept some of the costs associated with conservation practices on their own farm and did not always require payments equal to or above expected costs. In this way, farmers 
Table 5

Descriptive statistics of the characteristics of auction participants.

\begin{tabular}{lrrrrr}
\hline Characteristic & $\begin{array}{c}\text { Paulding } \\
\text { County }\end{array}$ & $\begin{array}{l}\text { Henry } \\
\text { County }\end{array}$ & $\begin{array}{l}\text { Wood } \\
\text { County }\end{array}$ & $\begin{array}{l}\text { Hancock } \\
\text { County }\end{array}$ & \multicolumn{1}{c}{ All } \\
\hline Number of participants & 12 & 10 & 16 & 11 & 49 \\
Participant characteristics & & & & & \\
Gender (\% male) & 100 & 100 & 100 & 100 & 100 \\
Average age (y) & 61 & 62 & 44 & 64 & 56 \\
Average farming experience (y) & 42 & 44 & 25 & 47 & 38 \\
Education beyond high school (\%) & 42 & 50 & 69 & 27 & 49 \\
Off-farm income > US $\$ 50,000(\%)$ & 33 & 50 & 44 & 55 & 45 \\
Average acres planted in 2012 & 1,580 & 1,076 & 1,848 & 1,190 & 1,477 \\
Member of environmental organization (\%) & 17 & 60 & 25 & 55 & 37 \\
Recruitment & & & & & \\
Soil and Water Conservation District (\%) & 100 & 44 & 56 & 72 & 69 \\
Farm bureau (\%) & 0 & 0 & 44 & 0 & 15 \\
Input supplier (\%) & 0 & 56 & 0 & 0 & 10 \\
Tax records (\%) & 0 & 0 & 0 & 27 & 6 \\
& & & & & \\
\hline
\end{tabular}

considered the payments more like a costshare and bid accordingly.

Table 6 presents the summary statistics of net bids across the auctions and figure 4 presents the frequency distributions. Mean net bids are highest in the auction for payments with BMP insurance, but the mean is pulled upward by several farmers with strong aversion to BMP insurance that bid significantly higher than they did in the payment auction.
Net bids are lowest for the tax credit, but due to the high variance and relatively small sample size, the difference between net bids in the tax credit auction and the auction for direct payments is not statistically significant.

Random effects regression techniques are used to estimate the regression model by controlling for farm and farmer characteristics while testing for effects of environmental preferences and differences in bidding behavior across incentive types. Relative to direct payment, the results reveal aversion to BMP insurance incentives, but no significant differences in preferences for tax credits or premiums tied to stewardship certification (table 7). The continuous dependent variable is the net bid-the difference between the per-acre bid to adopt conservation practices and the assigned per-acre cost of adopting those practices.

Relative to the auction in which farmers bid for a direct payment only, net bids were US\$14 higher on average when BMP insur-

\section{Figure 3}

Scatterplots that compare farmer bids and their assigned costs to implement conservation practices show that farmers bid both above and below their costs in all auctions. (a) shows direct payment, (b) shows direct payment with best management practice (BMP) insurance, (c) shows tax credit, and (d) shows premium tied to certification.

(a)

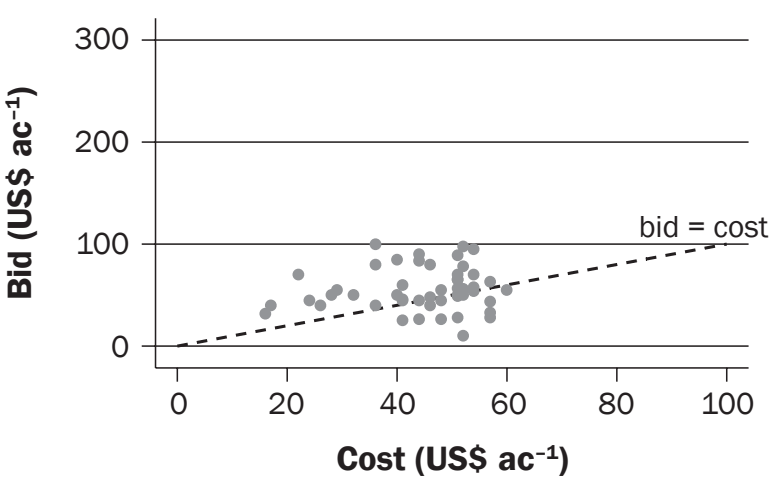

(c)

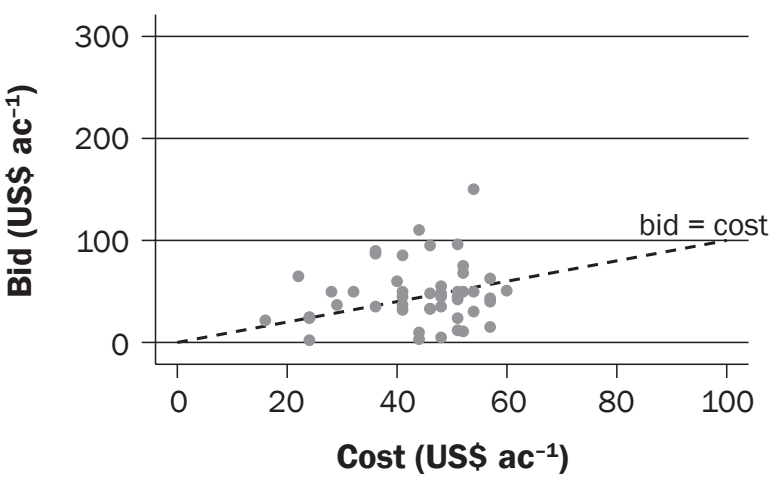

(b)

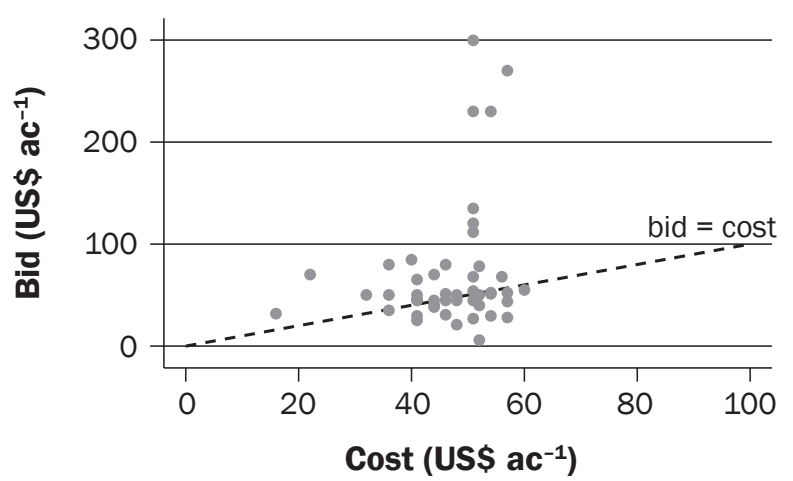

(d)

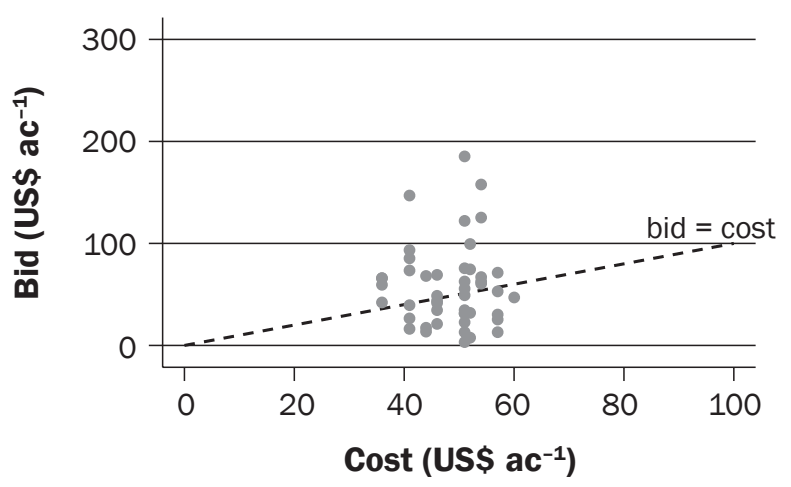




\section{Table 6}

Summary statistics of net bids (i.e., bid minus the cost of conservation practice implementation) for four incentive types.

\begin{tabular}{lrrllrr}
\hline Incentive offered in auction & $\boldsymbol{n}$ * & Mean & Std. dev. & Min & Median & \multicolumn{1}{c}{ Max } \\
\hline Payment & 49 & 11.0 & 22.7 & -42.0 & 7.0 & 64.0 \\
Payment with BMP insurance & 47 & 24.0 & 61.8 & -46.0 & 3.0 & 249.0 \\
Tax credit & 47 & 3.4 & 30.1 & -43.0 & -1.0 & 96.0 \\
Certification price premium & 47 & 8.7 & 40.3 & -47.4 & 2.3 & 134.2
\end{tabular}

*All 49 participants submitted bids in the auction for a conservation payment; however, only 47 bids were submitted in the auctions for the alternative incentives. Participants who chose not to submit bids varied among the three auctions.

ance (provided free to the farmer) was offered in addition to a direct payment. This result may seem counterintuitive if one expects required payments for BMP adoption to decrease with reduced risk, but debriefing after the auction revealed that many farmers were skeptical of BMP insurance and were uncertain about the administrative hurdles that the program may involve. Farmers stated that they lacked confidence that this type of BMP insurance program would pay indemnities in the event that yield loss on their farms from the adoption of conservation practices correlated poorly with county average effects. One farmer voiced his concern about how this type of insurance program would actually be administered, asking, "[How well] would county level outcomes really represent my farm? There are many different soil types, operators, and weather variability." He stated that these factors made him less interested in BMP insurance.

Net bids did not differ significantly among the payment, tax credit, and certification premium auctions. When asked about preferences between payments and tax credits, one farmer explained, "You would need to make the tax credit the same value as the payment, but I don't have a real preference." Another farmer said, "I like the idea of a tax reduction, but it is a tricky thing to think about." This sentiment was shared by four other farmers who voiced concerns about how tax credits would be administered. Expressing his opinion about certification price premiums, a farmer said, "I like the certification idea. You can get certified and then your premium just jumps per bushel. That's so easy. You just have to get certified and show that you're doing these practices."

When comparing the net bid in the BDM mechanism for certification premium to the auction for payments, we expected a lower bid for the premium due to the incentive compatible properties of the BDM mechanism. However, even considering this impact, we still find no significant differences among net bids. Therefore, we conclude that the certification premium performs no better than a payment. We further explore

\section{Figure 4}

Histograms of net bids for each auction show that the variance of net bids is smallest in the auction for direct payments and largest among net bids for payments with best management practice (BMP) insurance. (a) shows payment, (b) shows direct payment with BMP insurance, (c) shows tax credit, and (d) shows premium tied to certification.

(a)

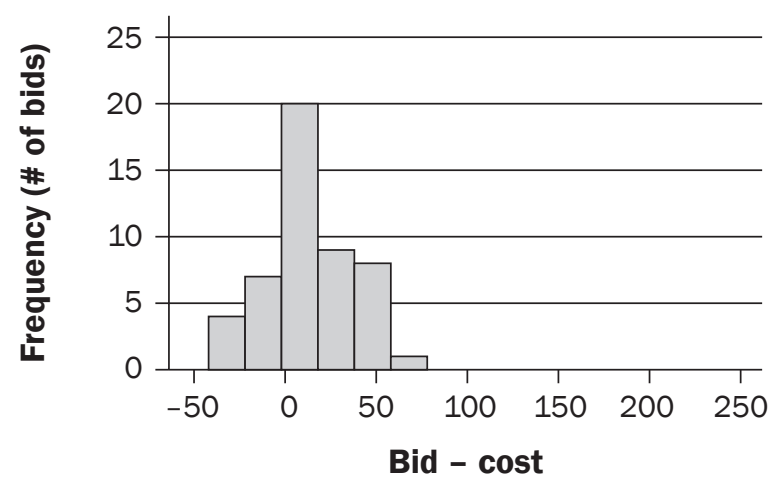

(c)

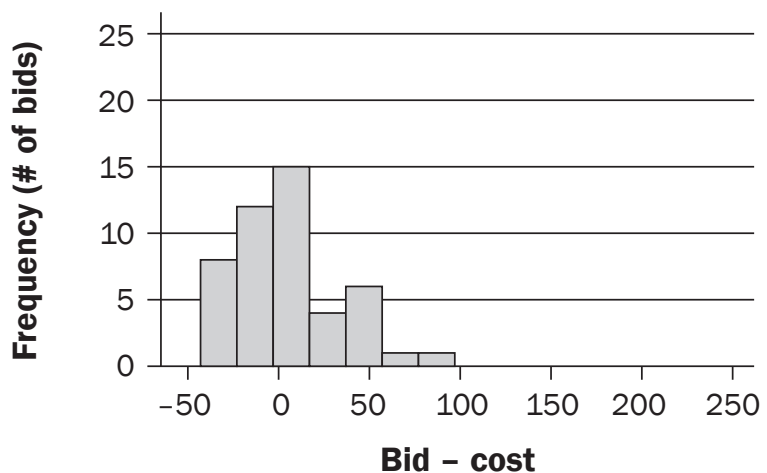

(b)

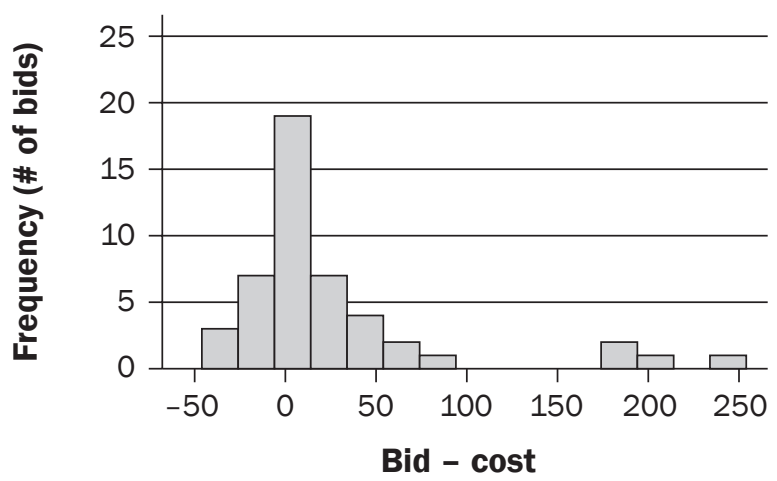

(d)

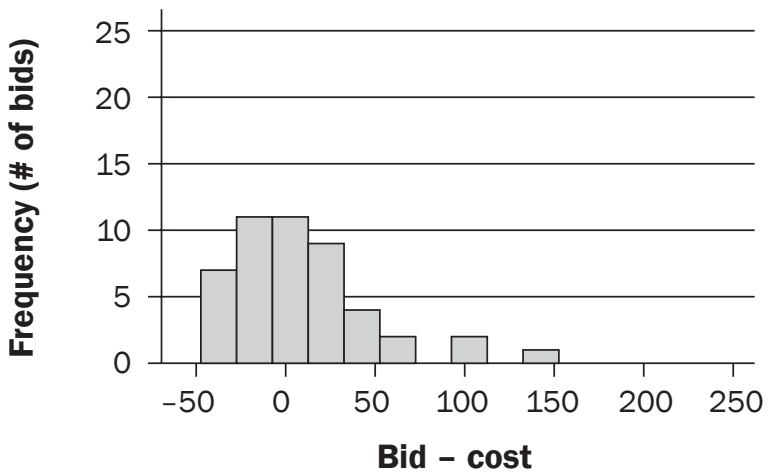


the cost-effectiveness of payments and price premiums in the following section. For a single payer, such as a government conservation agency, the results suggest that certification premiums are not more cost-effective than direct payments.

Among the three conservation practices, spring fertilizer application induced a large bid premium over costs. Average net bids increased by over US $\$ 21$ when spring fertilization was included. Although changing the timing of fertilizer application may seem costless, farmers explained that spring fertilization requires extra time in an already short planting window and increases the risk of delayed planting that results in yield losses. They also reported that driving equipment over wet fields in the spring increases soil compaction in the heavy soils that dominate much of the landscape in the Maumee Watershed, which can interfere with planting and decrease crop yields.

Farmers that were members of environmental organizations placed net bids almost US $\$ 18 \mathrm{ac}^{-1} \quad\left(\mathrm{US} \$ 44.48 \mathrm{ha}^{-1}\right)$ lower than nonmember farmers. If membership in an environmental organization is a valid proxy for environmental preferences, then the significance of this attribute supports rejecting the null hypothesis that environmental preferences have no effect on willingness to participate in conservation programs. Farmers who care about the environment are willing to accept lower financial incentives to adopt conservation practices that improve water quality.

Cost-Effectiveness of Conservation Incentives. To evaluate the relative cost-effectiveness of each incentive type, we construct contract supply curves to compare the cost to procure each unit of TP abatement across the different auctions in our experiment. Annual TP abatement is predicted using the SWAT (Bosch et al. 2011; LimnoTech 2013). It is important to recognize that these curves do not reflect the true cost to reduce TP because abatement is predicted for mock farms where farmers have hypothetical costs; therefore, we are not estimating farmers' true willingness to accept. Instead, we are comparing the relative outcomes of the auctions depending on the type of incentive offered. Figure 5 presents contract curves that were created by ordering the bids from all four auctions by the cost per pound of reduced TP runoff and plotting the cost to reduce each pound of TP runoff against the cumulative reductions in TP

Table 7

Determinants of net bids (bid minus assigned costs of conservation practices) for 49 farmer participants in experimental auctions, random effects regression model.

\begin{tabular}{|c|c|c|c|}
\hline Variable & Coefficient & Robust std. err. & $p$-value \\
\hline Cover crop dummy & -6.56 & 6.18 & 0.29 \\
\hline Conservation tillage dummy & -15.04 & 12.38 & 0.23 \\
\hline Spring fertilizer dummy & $21.60 * * *$ & 5.56 & 0.00 \\
\hline \multicolumn{4}{|l|}{ Type of auction } \\
\hline Direct payment & (baseline) & & \\
\hline BMP insurance & $14.64 *$ & 8.84 & 0.10 \\
\hline State tax credit & -5.84 & 4.15 & 0.16 \\
\hline Certification premium & -5.00 & 6.11 & 0.41 \\
\hline \multicolumn{4}{|l|}{ Mock farm assignment } \\
\hline Location A_2 & -9.75 & 11.64 & 0.40 \\
\hline Location B_1 & -7.09 & 10.76 & 0.51 \\
\hline Location B_2 & -2.94 & 11.47 & 0.80 \\
\hline Location C_1 & 1.84 & 10.34 & 0.86 \\
\hline Location C_2 & $-36.16 * * \star$ & 8.31 & 0.00 \\
\hline Location D_1 & -6.82 & 13.02 & 0.60 \\
\hline Location D_2 & -16.32 & 15.76 & 0.30 \\
\hline \multicolumn{4}{|l|}{ Farmer meeting } \\
\hline Henry County & $19.79 * * *$ & 6.17 & 0.00 \\
\hline Wood County & $16.88^{*}$ & 9.19 & 0.07 \\
\hline Hancock County & $39.32 * * *$ & 8.88 & 0.00 \\
\hline \multicolumn{4}{|l|}{ Demographics } \\
\hline Age $(y)$ & $-1.11 * *$ & 0.53 & 0.04 \\
\hline Education beyond high school (= 1 if yes) & 8.33 & 7.02 & 0.24 \\
\hline Farming experience $(\mathrm{y})$ & 0.68 & 0.63 & 0.28 \\
\hline Income (= 1 if $>$ US $\$ 50,000$ off-farm income) & -4.08 & 4.88 & 0.40 \\
\hline Acres planted in 2012 & -0.001 & -0.003 & 0.75 \\
\hline Environmental organization (= 1 if a member) & $-17.64 * * *$ & 6.68 & 0.01 \\
\hline Constant & $47.65 *$ & 26.36 & 0.07 \\
\hline$* p<0.1 \quad * * p<0.05 \quad * * * p<0.01$ & & & \\
\hline
\end{tabular}

runoff (i.e., cumulative environmental benefit). Figure $5 \mathrm{a}$ presents the contract curves for payments, BMP insurance, and tax credits, which overlap considerably and show no significant difference in cost-effectiveness of bids until the upper limit of the curve. Note that this analysis does not take into account the administrative costs involved with running a conservation program. One would expect that BMP insurance programs have higher administrative costs than PES programs that make direct payments. Therefore, cost-effectiveness of BMP insurance would be further reduced when total costs of the program are considered.

Figure $5 \mathrm{~b}$ compares contract curves for three levels of certification premiums to the base curve constructed from bids for direct payments. Points on the curve "Certification premium $-\mathrm{A}$ " represent the cost per pound of TP reduction if farmers were paid price premiums for corn and soybeans equal to their bids. In this scenario, cost-effectiveness of bids for price premiums is no different than for bids to receive direct payments. However, an environmental stewardship certification program would not pay farmers unique price premiums based on their willingness to accept or the amount of environmental benefits that their conservation actions provide. Instead, a certification program would set a price premium and allow farmers to opt-in and adopt the required practices or decline to participate. This type of program is not targeted to environmentally vulnerable sites, so cost-effectiveness is reduced relative to targeted conservation payments. Certification programs $\mathrm{B}$ and $\mathrm{C}$ (figure 5b) represent potential nontargeted incentive programs in which enrollment is determined by farmers' willingness to accept the established price premium. Price pre- 


\section{Figure 5}

(a) Contract supply curves for the reduction of total phosphorus (TP) runoff with direct payment, best management practices (BMP) insurance plus payment, and tax credit; and (b) contract supply curves for the reduction of TP runoff with direct payments and certification premiums.

(a)

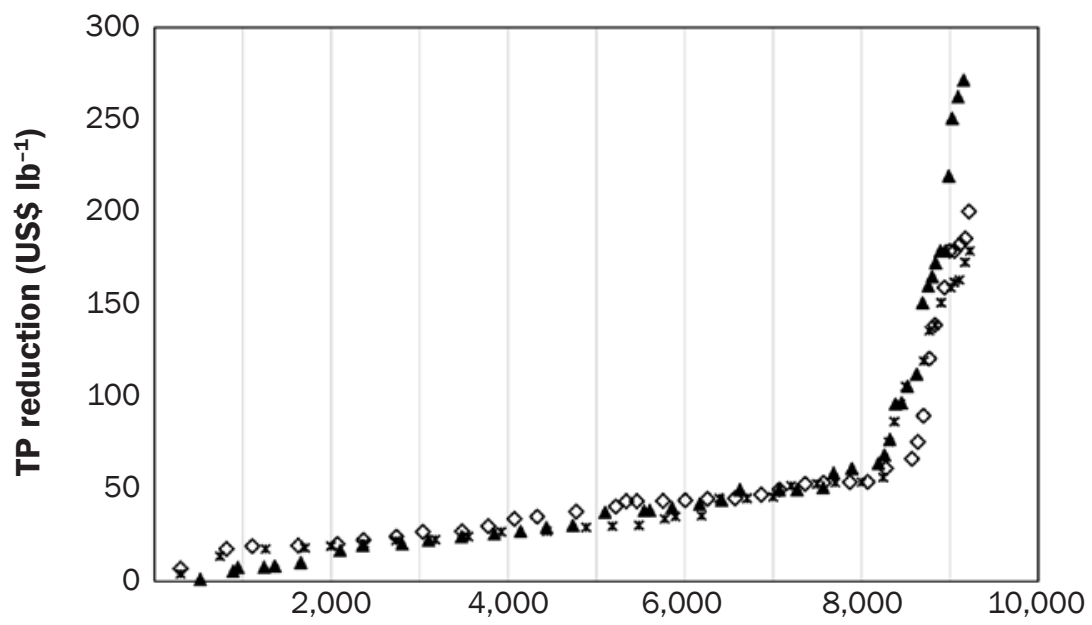

Cumulative environmental benefits (Ib TP reduction $\mathbf{y}^{-1}$ )

\section{Legend}

$\diamond$ Direct payment

(b)

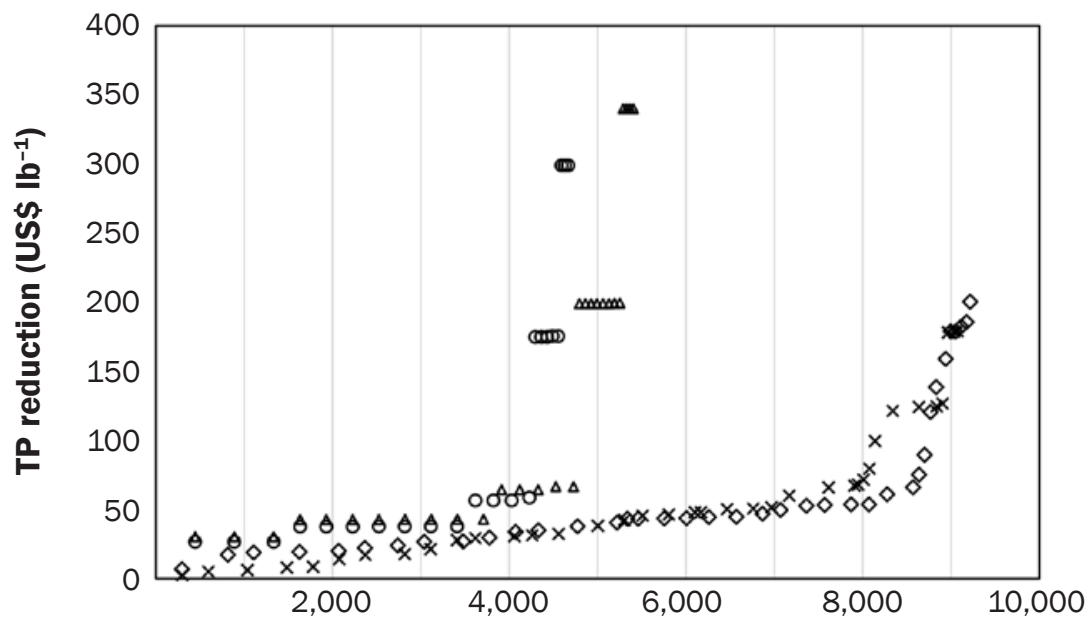

Cumulative environmental benefits (Ib TP reduction $\mathbf{y}^{-1}$ )

\section{Legend}

$\diamond$ Direct payment

- Certification premium - B

$\times$ Certification premium $-\mathrm{A}$

$\Delta$ Certification premium - C

\section{Certification premiums offered:}

$$
\begin{aligned}
A= & \text { premium bid } \\
B= & \text { average bid: } \\
& \text { US } \$ 0.43 \mathrm{bu}^{-1} \text { (corn) } \\
& \text { US } \$ 0.90 \mathrm{bu}^{-1} \text { (soybeans) } \\
\mathrm{C}= & \text { US } \$ 0.50 \mathrm{bu}^{-1} \text { (corn) } \\
& \text { US } \$ 1.00 \mathrm{bu}^{-1} \text { (soybeans) }
\end{aligned}
$$

miums for program $\mathrm{B}$ are set at US $\$ 0.43$ $\mathrm{bu}^{-1}\left(\mathrm{US} \$ 16.93 \mathrm{t}^{-1}\right)$ corn and US $\$ 0.90 \mathrm{bu}^{-1}$ (US $\$ 33.07 \mathrm{t}^{-1}$ ) soybeans, which were the mean bids submitted for the respective premiums. The contract curve for program B increases sharply after land with high environmental benefits is enrolled. The program then begins paying the same price premium to farmers with limited ecological impact, thus decreasing the overall cost-effectiveness of the program. Relative to program A and the auction for direct payments, fewer benefits are procured at a greater cost per unit of benefit. In program $\mathrm{C}$, the price premiums are increased to US $\$ 0.50$ and US $\$ 1.00 \mathrm{bu}^{-1}$ (US\$19.68 and US $\$ 36.74 \mathrm{t}^{-1}$ ) for corn and soybeans, respectively. Program C has greater overall environmental impact than program $\mathrm{B}$ because more farmers are willing to enroll in the program for the higher price premium. However, paying a higher premium means that farmers are paid more per unit of environmental impact. If the premium is paid in the market, this incentive may be acceptable, but in the context of agencies with limited conservation funding, there are more cost-effective ways to allocate economic incentives by targeting funds to cost-effective conservation proposals.

\section{Summary and Conclusions}

Well-designed conservation incentives are critical to improve environmental outcomes across agricultural landscapes. This research highlights the importance of understanding farmer preferences for different conservation incentives in order to design cost-effective agri-environmental programs in which farmers are willing to participate. Using experimental procurement auctions, we compare farmer bids for four different incentives including (1) direct payment, (2) payment coupled with BMP insurance, (3) tax credits, and (4) price premium tied to stewardship certification. We evaluate bidding behavior across these auctions to identify cost-effective incentives. Rather than finding one incentive type to be most cost-effective, we find two traits that lead to a less cost-effective incentive. First, when the incentive cannot spatially target conservation practices to vulnerable locations, environmental benefits (and hence cost-effectiveness) are reduced, as in the case of the certification price premium. Second, when farmers are skeptical of a particular incentive or they perceive that it will have high transaction costs, they 
will demand higher payments, as in the case of BMP insurance. See Palm-Forster et al. (2016b) for a more in-depth analysis about how transaction costs affect farmer participation and cost-effectiveness of conservation auctions. In this study, farmers were equally willing to accept direct payments and tax credits in exchange for implementing conservation actions.

Crop yield insurance linked to conservation practices, also called green insurance or BMP insurance, has been proposed as a way to facilitate the adoption of environmentally sound production practices when farmers are risk averse and misperceive the downside risk of these practices on farm profitability (Mitchell 2004; AFT 2012). However, results from our experimental auctions indicate that farmers often demand higher payments when coupled with BMP insurance (provided free to the farmer). Comments during debriefing suggest that farmers were skeptical of how well the program would work and they were wary of uncertain transaction costs associated with obtaining and implementing the policy. Considering the added costs that would be required for an organization to administer and oversee a BMP insurance program, this is a less cost-effective alternative to the direct payments alone. BMP insurance may be successful if it could be integrated into the current crop insurance market. However, past programs have found it difficult to generate support for BMP insurance in the private sector due to high transactions costs and uncertainty surrounding the new policy (Mitchell 2004; Campbell 2003).

Tax credits may be a worthwhile incentive for agricultural conservation, if designed correctly. Farmer bids for tax credits did not significantly differ from bids for payments, indicating farmers were indifferent between the two incentives. Farmers suggested that state tax credits would be insufficient to fund many conservation practices, but this form of incentive may be feasible for relatively inexpensive BMPs. The relative cost-effectiveness of the two contracts would depend on the overhead and administrative costs incurred by the government to manage the program. An important caveat not explored in this research is that our analysis of tax credits assumes that the farmer managing the land would benefit from tax incentives. In much of the Corn Belt, a significant portion of cropland is rented. In our sample of 49 producers, $38 \%$ of farmers rented-in twice as much land as they owned. Tax credits would have to be designed so that the person undertaking the conservation actions could benefit from the credits, whether it be the landowner or renter. Furthermore, there may be political resistance to a tax policy in which benefits are only available to owners and managers of land with high environmental impact.

Programs that certify environmental stewardship provide signals about farmers' actions to promote ecosystem health and can induce conservation actions if farmers value benefits from the certification (e.g., price premiums, increased market access, social recognition, or protection from future regulation). Results from our experimental auctions suggest that farmers are willing to enroll in stewardship certification programs that offer price premiums for certified crops. However, enrollment in such a program only depends on farmer willingness to accept the offered premium. Therefore, uniform price premiums would be paid to farmers for adoption of practices regardless of the environmental vulnerability of their cropland, resulting in more variable and less cost-effective outcomes relative to targeted PES or tax credit programs.

Understanding farmer preferences for different types of conservation incentives is critical to design cost-effective agri-environmental programs. Our research begins to fill this gap by experimentally testing farmers' willingness to participate in conservation programs offering a variety of incentives for adoption of conservation practices. Farmers prefer incentive programs with low transaction costs such as those offering direct payments or tax credits. Compared to nontargeted policies like environmental stewardship certification, agri-environmental programs that can successfully target conservation incentives to producers with environmentally sensitive cropland are more cost-effective.

\section{Acknowledgements}

For their help developing the mock farms used in the auction experiment and for simulating best management practices implementation using the Soil and Water Assessment Tool (SWAT) to predict phosphorus reductions, the authors thank Todd Redder, P.E., a senior environmental and water resource engineer, and Joseph V. DePinto, Ph.D., a senior scientist, at LimnoTech in Ann Arbor, Michigan. Farmer recruitment was critical in this project and was facilitated by the Ohio Soil and Water Conservation Districts, Ohio Farm Bureau, and The Farmer's Elevator Grain and Supply Association in New Bavaria, Ohio. For their on-the-ground support to make the auctions successful, the authors thank Gary Pennell, a certified crop advisor at The Farmers Elevator, and two former Michigan State University students, Brad Kells (currently a doctoral student in economics at George Mason University in Fairfax,Virginia) and Kathleen Sprouse (currently the Quality Assurance and Food Safety Lead at Earthbound Farm in San Juan Bautista, California). We also thank audiences at Michigan State University, Iowa State University, USDA-Economic Research Service (ERS), and University of Delaware for their helpful feedback. Financial support for the auctions was provided by the Great Lakes Protection Fund through The Nature Conservancy and supplementary funds were provided by the Kellogg Biological Station's Long-term Ecological Research (KBS LTER) Project, MSU AgBioResearch, and the USDA National Institute of Food and Agriculture. Finally, the authors thank the 51 farmer participants who attended the auction sessions and shared valuable insights about conservation and farming in the Lake Erie Basin.

\section{References}

AFT (American Farmland Trust). 2012. What is the BMP Challenge? http://blog.farmland.org/ what-is-the-bmp-challenge/.

Baerenklau, K.A. 2005. Some simulation results for a green insurance mechanism. Journal of Agricultural and Resource Economics 30(1):94-108.

Becker, G., M. DeGroot, and J. Marschak. 1964. Measuring utility by a single-response sequential method. Behavioral Science 9(3):226-36.

Bosch, N.S., J.D. Allan, D.M. Dolan, H. Han, and R.P. Richards. 2011. Application of the Soil and Water Assessment Tool for six watersheds of Lake Erie: Model parameterization and calibration. Journal of Great Lakes Research 37(2):263-71, doi:10.1016/j. jglr.2011.03.004

Campbell, S. 2003. Insuring best management practices. Journal of Soil and Water Conservation 58(6):116A-117A

Cason, T.N., L. Gangadharan, and C. Duke. 2003. A laboratory study of auctions for reducing non-point source pollution. Journal of Environmental Economics and Management 46(3):446-71, doi:10.1016/ S0095-0696(03)00026-3.

Claassen, R., A. Cattaneo, and R. Johansson. 2008. Costeffective design of agri-environmental payment programs: U.S. experience in theory and practice. Ecological Economics 65(4):737-52, doi:10.1016/j. ecolecon.2007.07.032.

DeVuyst, E.A., andV. Ipe C. 1999. A group incentive contract to promote adoption of best management practices. Journal of Agricultural and Resource Economics 24(2):367-382.

Edwards-Jones, G. 2006. Modelling farmer decision-making: Concepts, progress and challenges. Animal Science 82(06):783-90, doi:10.1017/ASC2006112. 
Feather, P.M., and G.S. Amacher. 1994. Role of information in the adoption of best management practices for water quality improvement. Agricultural Economics 11(23):159-70, doi:10.1016/0169-5150(94)00013-1.

Gassman, P.W., M.R. Reyes, C.H. Green, and J.G. Arnold. 2007. The Soil and Water Assessment Tool: Historical development, applications, and future research directions. Ames, IA: Center for Agricultural and Rural Development, Iowa State University. http://publications. iowa.gov/archive/00005419/01/paper_12744.pdf.

Hellerstein, D., N. Higgins, and M. Roberts. 2015. Options for Improving Conservation Programs: Insights from Auction Theory and Economic Experiments (No. ERR-181). Washington, DC: USDA Economic Research Service.

Horowitz, J.K., L. Lynch, and A. Stocking. 2009 Competition-based environmental policy: An analysis of farmland preservation in Maryland. Land Economics 85(4):555-75.

IJC (International Joint Commission). 2014. A Balanced Diet for Lake Erie: Reducing Phosphorus Loadings and Harmful Algal Blooms. A Report of the Lake Erie Ecosystem Priority. http://www.ijc.org/files/ publications/2014\%20IJC\%20LEEP\%20REPORT.pdf.

Johnson, L.T., D.B. Baker, R.B. Confesor, K.A. Krieger, and R.P. Richards. 2014. Research to help Lake Erie: Proceedings of the "Phosphorus along the Land-RiverLake Continuum" research planning and coordination workshop. Journal of Great Lakes Research 40(3):57477, doi:10.1016/j.jglr.2014.07.001.

Juutinen, A., E. Mäntymaa, and M. Ollikainen. 2013. Landowners' conservation motives and the size of information rents in environmental bidding systems. Journal of Forest Economics 19(2):128-48, doi:10.1016/j.jfe.2012.12.001.

Kleinman, P.J.A., D.R. Smith, C.H. Bolster, and Z.M. Easton. 2015. Phosphorus fate, management, and modeling in artificially drained systems. Journal of Environmental Quality 44(2):460.

Kroeger, T., and F. Casey. 2007. An assessment of marketbased approaches to providing ecosystem services on agricultural lands. Ecological Economics 64(2):321-32, doi:10.1016/j.ecolecon.2007.07.021.

Lambert, D.M., P. Sullivan, R. Claassen, and L. Foreman. 2007. Profiles of U.S. farm households adopting conservation-compatible practices. Land Use Policy 24(1):72-88, doi:10.1016/j.landusepol.2005.12.002.

Lichtenberg, E. 2004. Cost-responsiveness of conservation practice adoption: A revealed preference approach. Journal of Agricultural and Resource Economics 29(3):420-35, doi:10.2307/40987242.

LimnoTech. 2013. Tiffin River Great Lakes Tributary Modeling Program: Development and Application of the Tiffin River Watershed Soil and Water Assessment Tool (TRSWAT). Ann Arbor, MI: LimnoTech.

Lusk, J.L., C. Alexander, and M.C. Rousu. 2007. Designing experimental auctions for marketing research: The effect of values, distributions, and mechanisms on incentives for truthful bidding. Review of Marketing Science 5(1), https://doi.org/10.2202/1546-5616.1059.

Lusk, J.L., and J.F. Shogren. 2007. Experimental Auctions: Methods and Applications in Economic and Marketing Research. New York: Cambridge University Press.

Ma, S., S.M. Swinton, F. Lupi, and C. Jolejole-Foreman. 2012. Farmers' willingness to participate in paymentfor-environmental-services programmes. Journal of Agricultural Economics 63(3):604-26, doi:10.1111/ j.1477-9552.2012.00358.x.

Mitchell, P.D. 2004. Nutrient best management practice insurance and farmer perceptions of adoption risk. Journal of Agricultural and Applied Economics 36(3):657-73.

Mitchell, P.D., and D.A. Hennessy. 2003. Factors determining best management practice adoption incentives and the impact of green insurance. In Risk Management and the Environment: Agriculture in Perspective, eds. B.A. Babcock, R.W. Fraser, and J.N. Lekakis, 52-66. Netherlands: Springer. http://link.springer.com/ chapter/10.1007/978-94-017-2915-4_4.

Norris, P.E., D.B. Schweikhardt, and E.A. Scorsone. 2008. The instituted nature of market information. In Alternative Institutional Structures: Evolution and Impact, eds. S.S. Batie and N. Mercuro, 330-48. London: Routledge.

Palm-Forster, L.H. 2015. Cost-effective conservation programs to enhance ecosystem services in agricultural landscapes. PhD dissertation, Michigan State University. http://search.proquest. com/pqdt/docview/1748077791/abstract/ A801AC8B89324793PQ/1.

Palm-Forster, L.H., F. Lupi, and M. Chen. 2016a. Valuing Lake Erie beaches using value and function transfers. Agricultural and Resource Economics Review 45(2):270-292.

Palm-Forster, L.H., S.M. Swinton, F. Lupi, and R.S. Shupp. 2016b. Too burdensome to bid: Transaction costs and pay-for-performance conservation. American Journal of Agricultural Economics 98(5):1314-1333, http:// dx.doi.org/10.1093/ajae/aaw071.

Palm-Forster, L.H., S.M. Swinton, T.M Redder, J.V. DePinto, and C.M.W. Boles. 2016c. Using conservation auctions informed by environmental performance models to reduce agricultural nutrient flows into Lake Erie. Journal of Great Lakes Research 42(6):1357-1371, http://dx.doi.org/10.1016/j.jglr.2016.08.003.

Peterson, J.M., C.M. Smith, J.C. Leatherman, N.P. Hendricks, and J.A. Fox. 2014. Transaction costs in payment for environmental service contracts. American Journal of Agricultural Economics 97(1):219-38, doi:10.1093/ ajae/aau071.

Prokopy, L.S., K. Floress, D. Klotthor-Weinkauf, and A. Baumgart-Getz. 2008. Determinants of agricultural best management practice adoption: Evidence from the literature. Journal of Soil and Water Conservation 63(5):300-311, doi:10.2489/jswc.63.5.300.
Reichelderfer, K., and W.G. Boggess. 1988. Government decision making and program performance: The case of the conservation reserve program. American Journal of Agricultural Economics 70(1):1-11, doi: $10.2307 / 1241970$

Scavia, D., J.D. Allan, K.K. Arend, S. Bartell, D. Beletsky, N.S. Bosch, S.B. Brandt, R.D. Briland, I. Daloglu, J.V. DePinto, et al. 2014. Assessing and addressing the re-eutrophication of Lake Erie: Central basin hypoxia. Journal of Great Lakes Research 40(2):226-46, doi:10.1016/j.jglr.2014.02.004

Selman, M., S. Greenhalgh, M. Taylor, and J. Guiling. 2008. Paying for environmental performance: Potential cost savings using a reverse auction in program sign-up. Environmental Markets: Farm Bill Conservation Programs No.5. WRI Policy Note. Washington, DC: World Resources Institute.

Stumpf, R.P., T.T. Wynne, D.B. Baker, and G.L. Fahnenstiel. 2012. Interannual variability of cyanobacterial blooms in Lake Erie. PLoS ONE 7(8):e42444, doi:10.1371/journal.pone.0042444.

USDA NASS (National Agricultural Statistics Service). 2014. Quick Stats Tools. Washington, DC: USDA National Agricultural Statistics Service. https://www. nass.usda.gov/Quick_Stats/.

USEPA (US Environmental Protection Agency). 2016. Governments of Canada and the United States Announce Phosphorus Reduction Targets of 40 Percent to Improve Lake Erie Water Quality and Reduce Public Health Risk. Speeches, Testimony and Transcripts. Washington, DC: US Environmental Protection Agency. https://www.epa.gov/newsreleases/ governments-canada-and-united-states-announcephosphorus-reduction-targets-40-percent.

Wilson, R.S., G. Howard, and E.A. Burnett. 2014. Improving nutrient management practices in agriculture: The role of risk-based beliefs in understanding farmers' attitudes toward taking additional action. Water Resources Research 50(8):6735-46, doi:10.1002/ 2013WR015200. 